\title{
A New Slurry-Based Method of Preparation of Specimens of Sand Containing Fines
}

\begin{abstract}
A new method of specimen reconstitution is presented that is appropriate for element testing of sands containing either plastic or nonplastic fines. The method allows reconstitution of homogeneous, saturated specimens of sands containing fines whose stress-strain response closely resembles the stress-strain response of natural soil deposits formed underwater (e.g., alluvial and offshore submarine deposits, hydraulic fills, and tailings dams). A procedure is described to evaluate the maximum void ratio $\left(e_{\max }\right)$ of sands containing fines under conditions that more appropriately represent soil deposition at its loosest state in aquatic environments. For soils deposited in water, the data obtained with the procedure proposed in this paper suggest that ASTM D 4254 overestimates the $e_{\max }$ of sands containing plastic fines and underestimates the $e_{\max }$ of sands containing nonplastic fines.
\end{abstract}

KEYWORDS: silty sand, clayey sand, fines, maximum and minimum void ratios, specimen reconstitution method, slurry deposition

\section{Introduction}

Even though satisfactory techniques to obtain high-quality clay samples from the field for laboratory testing have been developed over the years, sampling of undisturbed cohesionless soil specimens remains a much more challenging task. As a result, laboratory testing of these soils has been almost exclusively done on reconstituted specimens. A variety of specimen preparation techniques have been developed for reconstitution of clean sand specimens in the laboratory. The most important questions defining a laboratory study of clean sands are the following: (1) Which sample preparation method can more closely simulate the structure and the actual stress-strain response of the soil being modeled? and (2) How can the limitations of the method be quantified?

In spite of the extensive research on "textbook" soils, many man-made and naturally formed deposits of geomaterials are neither clean sands nor pure clays. In part because specimen reconstitution and testing of nontextbook soils entail additional experimental difficulties, limited systematic studies have been carried out to investigate the behavior of these soils. This becomes particularly evident if one looks critically at the suitability of currently available specimen reconstitution techniques. The present paper presents experimental techniques that can be used to reconstitute specimens of sands containing small amounts of fines, either plastic or nonplastic. To provide for a simpler, more compact terminology, mixtures containing nonplastic or plastic fines (less than $15 \%$ by weight) are simply referred to as silty or clayey sands, respectively.

\section{Background}

Interest in research on the mechanical behavior of sands containing small amounts of fines has increased mainly because these soils were linked to liquefaction-related damage during recent earthquakes in Turkey, Japan, Taiwan, and the United States. Most pio-

\footnotetext{
Manuscript received June 9, 2005; revised June 18, 2007; accepted for publication July 9, 2007; published online September 2007.

${ }^{1}$ Assistant Professor, Colorado State University, Fort Collins, CO 80523.

${ }^{2}$ Assistant Professor, Purdue University, West Lafayette, IN 47907.
}

neering studies on soil liquefaction dealt only with clean sands, as clays and sands containing fines were considered to have a substantially higher resistance to liquefaction than clean sands.

A few important issues need to be addressed in the study of sands containing fines. First, a careful choice of how to quantify density is required for a logical, consistent treatment of the mechanical response of these soils. Secondly, analyses based exclusively on density and stress state are not sufficient for these materials, as the soil structure (and thus specimen preparation) is a key determinant of their behavior (Leroueil and Vaughan 1990; Mitchell and Soga 2005; Yamamuro and Wood 2004). Lastly, not only fines content, but also plasticity, needs to be properly accounted for. In the present paper, we focus our discussion on the limiting densities (or void ratios) and on the preparation of reconstituted specimens of sands with either plastic or nonplastic fines.

\section{Limiting Void Ratios}

The determination of limiting void ratios (or densities) of sandy soils has been the subject of many studies (e.g., Kolbuszewski 1948; Townsend 1973; Vaid and Negussey 1984; Youd 1973). Several factors have been shown to affect the maximum and minimum densities, such as the method used for $e_{\min }$ and $e_{\max }$ determination, soil grain-size distribution, and particle angularity (Kolbuszewski 1948; Vaid and Negussey 1984; Youd 1973). Considering some simple packing geometries, it can be demonstrated mathematically that the limiting void ratios of idealized single-sized spherical packings are equal to

$$
e_{\min }=\frac{3 \sqrt{2}-\pi}{\pi} \approx 0.35
$$

and

$$
e_{\max }=\frac{6-\pi}{\pi} \approx 0.91
$$

for tetrahedral and simple cubic arrangements, respectively (Farouki and Winterkorn 1965; Lade et al. 1998). 
In these idealized arrangements, there are no flaws or missing particles, and the particles are solid spheres perfectly positioned. In contrast, silty and clayey sands are soils composed of at least two distinct particle sizes. The simplest case of binary packing is one containing uniform fractions of coarse and fine particles. For simplicity, both fractions may be assumed to have uniform gradations, although their blending could result in a gap-graded material. Idealized packing of binary mixtures and mixtures composed of more than two particle sizes have also been studied (e.g., Lade et al. 1998; McGeary 1961). The effect of the fines content (FC), which is defined here as the ratio of the dry weight of fines to the total dry weight of solid particles, on the theoretical variation of the limiting void ratios (either $e_{\max }$ or $e_{\min }$ ) of binary spherical packings can be represented by a downward chevron-type diagram with the horizontal and vertical axes defining the fines content and void ratio of the reference system, respectively. Mixtures with finer fractions composed of hollow or defective particles may achieve higher void ratios than those with solid finer particles. Experimental evidence (Ovando-Shelley and Perez 1997; Pitman et al. 1994; Townsend 1973) suggests that the limiting void ratios also depend on other intrinsic characteristics of the coarse fraction and, even more so, on the intrinsic characteristics of the finer fraction of the soil (i.e., plasticity, mineralogy, and micro-structural arrangement).

The limiting void ratios $e_{\max }$ and $e_{\min }$ are also known to be affected by the method used in their determination (Kolbuszewski 1948; Townsend 1973; Vaid and Negussey 1984; Youd 1973). Thus, $e_{\max }$ and $e_{\min }$ are not necessarily the absolute limiting void ratios of a given soil, but rather the void ratios at the loosest and densest states produced by a particular set of laboratory test procedures. Vaid and Negussey (1984) showed that sand grains reach terminal velocity almost instantly during pluviation in water, resulting in $e_{\max }$ values that are unaffected by the drop height. On the other hand, air pluviation of dry sand produces different $e_{\max }$ values depending on the particle drop height used during the test. In order to minimize the effect of factors related to the procedure used in limiting void ratio determination, ASTM International and the Japanese Geotechnical Society (JGS) created standards for determining the minimum and maximum void ratios of cohesionless soils containing up to $15 \%$ and $5 \%$ fines, respectively. Cubrinovski and Ishihara (2002) claim that the JGS methods can be used for sands containing up to $30 \%$ fines.

While the use of saturated samples for $e_{\min }$ determination has been suggested in the literature (Bolton 1986) and the use of wet samples is even prescribed by some standards (e.g., ASTM D 4253-Maximum Index Density and Unit Weight of Soils Using a Vibratory Table), none of the available standard methods (e.g., ASTM D 4254-Minimum Index Density and Unit Weight of Soils and Calculation of Relative Density, JGS) provide a procedure for the determination of $e_{\max }$ of sands deposited through water or slurry. The implication is that the maximum void ratio of natural soil deposits, such as alluvial and offshore submarine soils, hydraulic fills, and tailings dams, may not be properly assessed by current standard techniques. This is because all standard techniques available for $e_{\max }$ determination recommend using oven-dried samples.

\section{Specimen Preparation}

It is well known that the mechanical response of sandy soil specimens reconstituted in the laboratory depends on the method used to prepare the specimens. In the case of sands containing fines, the effect is even more pronounced, as additional issues (particle seg- regation, specimen homogeneity, and adequacy of the fabric of the reconstituted specimens) arise because of the presence of the finer fraction within the soil structure. The most widely used reconstitution techniques for sands containing fines are: (1) moist tamping (MT); (2) air (or dry) pluviation (AP); and (3) water (or wet) pluviation (WP) and its variants, such as slurry deposition (SD) techniques. Loose sand specimens (with or without fines) prepared using these three methods of sample preparation and tested under identical conditions show quite different stress-strain response.

Vaid (1994) argued that the MT technique neither simulates the fabric of alluvial soil deposits nor guarantees specimen uniformity. While homogeneity of MT specimens is tacitly assumed, a limited number of studies have evaluated this assumption in a more systematic manner (Castro 1969; Frost and Park 2003; Mulilis et al. 1977; Vaid et al. 1999), generally demonstrating the inadequacy of the MT technique to reconstitute specimens in the laboratory (Frost and Park 2003). Furthermore, this technique enables specimen reconstitution at void ratios that may be too high and thus not possible for natural soil deposits formed underwater (Kuerbis 1989; Vaid 1994). Loose, saturated MT specimens of sands containing fines are typically the most contractive (Thevanayagam et al. 2002; Vaid et al. 1999).

The fabric of loose specimens of silty sands obtained by AP also has been shown to be highly contractive (Lade and Yamamuro 1997; Yamamuro and Covert 2001; Zlatovic and Ishihara 1997). Lade and Yamamuro (1997) attributed the highly contractive behavior of AP silty sands to the unstable floating fabric obtained with their method of specimen preparation (Yamamuro and Wood 2004).

Homogeneous specimens of uniform sand can be prepared by pluviation in either air or water. WP is preferable as it produces initially saturated specimens that are easy to replicate (Vaid and Negussey 1988) and have fabric and behavior similar to that of natural alluvial soils (Ghionna and Porcino 2006; Oda et al. 1978), but this technique cannot be used for sands containing fines because of particle segregation (Kuerbis and Vaid 1988). SD methods of specimen preparation have been proposed that, at the same time, avoid segregation of the fines and produce the same type of fabric and stress-strain response of WP specimens. Ishihara et al. (1978) presented a SD technique for silty sand and sandy silt but their specimens were not very homogeneous for FC values between $30 \%$ and $80 \%$. Kuerbis and Vaid (1988) developed a SD method that produces homogenous specimens (e.g., Emery et al. 1973) of well-graded sands and silty sands. A version of this technique was used to prepare triaxial specimens of sands containing up to $20 \%$ nonplastic silt (Salgado et al. 2000) and sands containing small amounts of either nonplastic (Carraro et al. 2003; Carraro et al. 2005; Murthy et al. 2007) or plastic (Carraro 2004) fines.

Direct comparisons between the behavior of truly undisturbed clean (Ghionna and Porcino 2006) and silty sand (Vaid et al. 1999) specimens retrieved by in situ ground freezing and their corresponding reconstituted counterparts after consolidation to identical initial states have been carried out. The results showed that the fabric generated by WP closely simulates that of natural alluvial and hydraulic fill sand. This was corroborated by Hoeg et al. (2000), who also noted dramatic differences in the undrained stress-strain response of "undisturbed" and MT silt and silty sand specimens tested at the same soil state. In summary, a critical review of the 


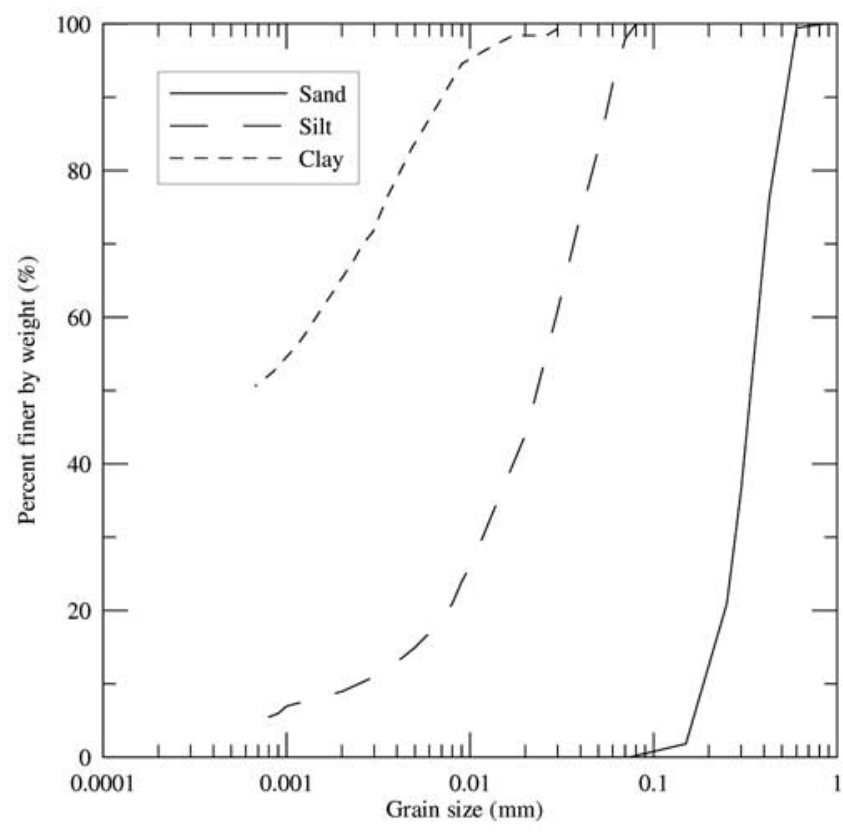

FIG. 1-Grain size distribution curves of the materials tested.

literature suggests that water deposition methods simulate best the in situ fabric and stress-strain response of most liquefiable soil deposits (alluvial deposits, hydraulic fills, tailings dams) of sands with or without fines. In this paper, a specimen reconstitution technique that can be used to prepare specimens of sands containing fines is presented.

\section{Experimental Program}

\section{Materials}

Various mixtures of silty and clayey sands were obtained in the laboratory by combining a standard silica sand with either nonplastic silt or kaolin clay. The sand used was ASTM C 778 (Standard specification for standard sand) graded sand, commonly known as Ottawa sand. Figure 1 shows the grain size distribution of this sand, which is classified as SP according to the USCS. Sand particle diameters range from $0.08 \mathrm{~mm}$ to $0.7 \mathrm{~mm}$. The coefficient of uniformity $C_{\mathrm{u}}$ of the sand is 1.89 , and its mean grain size $D_{50}$ is $0.31 \mathrm{~mm}$. The ASTM minimum and maximum void ratios $e_{\min }$ and $e_{\max }$ are 0.495 and 0.767 , respectively. Ottawa sand particles are round to subround.

The nonplastic silty sand specimens were prepared with \#106 Sil-Co-Sil ground silica manufactured by U. S. Silica Co., Ottawa, IL. This is a nonplastic silt that passes the \#200 sieve and is composed of $\mathrm{SiO}_{2}(99.8 \%)$, with $\mathrm{Al}_{2} \mathrm{O}_{3}(0.05 \%)$ and $\mathrm{Fe}_{2} \mathrm{O}_{3}$ $(0.035 \%)$ as secondary components. While the mineralogical composition of the silt and sand materials are identical (silica), their particle shapes are quite distinct (the silt particles are angular in shape).

EPK air-floated kaolin clay produced by Feldspar Co., Edgar, FL, was used to prepare the clayey sand specimens. Kaolinite is the predominant clay mineral present in this clay (97\%). The average particle size and surface area are equal to $1.02 \mu \mathrm{m}$ and
$25.59 \mathrm{~m}^{2} / \mathrm{g}$, respectively. This clay has a plasticity index of 26 and a liquid limit of 60 . The grain size distribution curves of both silt and clay are presented in Fig. 1.

The mixtures investigated in this study consisted of sand with 2 , 5, 10, and $15 \%$ silt and 2, 5, and $10 \%$ clay. Dry mixtures were prepared by first weighing the desired amount of dry sand and fines and then vigorously shaking the materials within a closed container until mixture homogeneity was observed. The specific gravities $G_{\mathrm{S}}$ of the sands tested in this study ranged from 2.65 to 2.66.

\section{Experimental Methods}

Limiting Void Ratios - The addition of fines to a host sand affects its basic properties in several ways. Two approaches were followed to evaluate the effect of fines on the $e_{\min }$ and $e_{\max }$ of silty and clayey sands. In the first approach, minimum and maximum densities of sands containing fines were determined according to the ASTM standards. The second approach consisted of developing a method to determine the minimum density (or $e_{\max }$ ) of silty and clayey sands deposited through water or slurry. Both approaches are described below.

ASTM Limiting Void Ratios-ASTM D 4253 and ASTM D 4254 were used to determine the $e_{\min }$ and $e_{\max }$ of the silty and clayey sands tested. Pilot tests performed by Bandini (2000) on nonplastic silty sand mixtures identical to the ones used in the present study showed that, among the three procedures recommended by ASTM D 4254 for $e_{\max }$ determination (methods A, B, and $\mathrm{C}$ ), method $\mathrm{B}$ renders the most reproducible results. In this method, dry soil is carefully poured in a thin-wall cylindrical tube previously positioned inside an ASTM standard mold (the $2830-\mathrm{cm}^{3}$ mold was used in this study). The tube is then quickly raised allowing the soil to deposit within the mold in the most reproducible loose state possible. This method was used by Salgado et al. (2000) to determine $e_{\max }$ of nonplastic silty sands, and, in the present study, it was used for both silty sand and clayey sand. Minimum void ratios were determined using test method $1 \mathrm{~A}$. In this procedure, dry soil is densified in the same ASTM mold described above using an electromagnetic, vertically vibrating table at a frequency of $60 \mathrm{~Hz}$. The vibrating table was calibrated according to Kaufman et al. (1979), as recommended by ASTM D 4253. A value of double amplitude of vertical vibration of $0.379 \mathrm{~mm}$ was used, as this value was found to be optimum for various mixtures of clean and nonplastic silty sands (Salgado et al. 2000).

Slurry-Deposition Maximum Void Ratio-As explained previously, ASTM procedures for $e_{\max }$ determination require use of oven-dried samples. In order to investigate the effect of water as the medium through which soil deposition occurs on the $e_{\max }$ values of clean, silty, and clayey sands, a new procedure was developed. In this procedure, sand samples are allowed to settle within a vertical cylindrical plexiglass tube completely filled by either water or fines slurry, depending on whether clean sands or sands containing fines are to be tested. The tube is a combination of a cylindrical plexiglass mold attached to a collar, as shown in Fig. 2. The mold is closed at the bottom by a plexiglass plate, and its dimensions are proportional to the ASTM standard mold dimensions (diameter/height ratio $\approx 1$ ). The smallest dimension of the plexiglass mold $d$ is 73 times (about two orders of magnitude) 


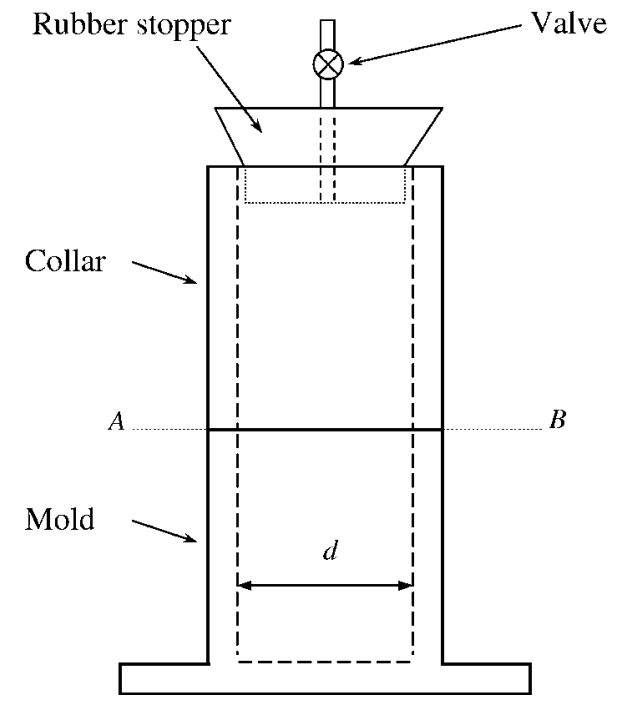

FIG. 2-Apparatus used for determination of slurry deposition maximum void ratio.

larger than the maximum particle size of the samples tested, suggesting that scale effects should be negligible. A description of the method is given below:

(1) The mold is placed on a horizontal surface over a thin rubber mat to minimize vibration during testing, and the collar is secured and sealed on top of it. The mold is then filled with deaired water and a funnel is placed on the upper end of the collar.

(2) The soil sample is slowly poured through the funnel to minimize entrapment of air bubbles during sedimentation of the soil particles. The amount of soil used should be just enough to fill the mold. Only about $2-3 \mathrm{~mm}$ of saturated soil should remain above line $A B$ (Fig. 2). This can be easily accomplished by previously determining the amount of dry sand required to fill the mold in its loosest dry state. After the whole sample is poured into the device partially filled with deaired water, the funnel is removed and the collar is topped up with additional deaired water. A rubber stopper, which has a valve attached to its center, is used to seal the system (Fig. 2).

(3) The stopper valve is closed and the sample is agitated vigorously by shaking and turning the device upside-down several times. The device is then placed back on the rubber mat and allowed to rest for a few seconds, allowing any entrapped air bubbles to move up towards the top of the collar (right below the rubber stopper). The stopper valve is opened, and the stopper is taken out so that the bubbles can be removed by topping up the collar with more deaired water (this process may be repeated several times until all visible air bubbles are removed). Next, the system is agitated for the last time and, once mixture homogeneity is achieved, it is carefully placed back on the rubber mat as gently as possible, and the soil sample is allowed to settle within the tube. After $20 \mathrm{~min}$, the stopper valve is opened and the stopper is gently taken away. The water and/or fines slurry deposited in the collar is removed at this stage.

(4) The collar is taken away, and the top of the mold is leveled off with a straight edge in two strikes (from the center of the mold outwards). Then, the dry weights of the sand $W_{\text {sand }}$ and fines $W_{\text {fines }}$, if present, are determined, and the total dry weight of soil solids in the specimen $\left(W_{\mathrm{s}}=W_{\text {sand }}+W_{\text {fines }}\right)$ calculated. Since the volume of the mold $V_{\mathrm{m}}$ is known, the maximum void ratio $e_{\max }^{\prime}$ of the soil deposited through a suspension of water or fines slurry can be calculated from:

$$
e_{\max }^{\prime}=\frac{G_{s} \gamma_{w} V_{m}}{W_{s}}-1
$$

where $G_{s}=$ specific gravity of soil and $\gamma_{w}=$ unit weight of water.

Specimen Preparation -A SD method of specimen reconstitution was developed based on an earlier method originally proposed by Kuerbis and Vaid (1988) for silty and well-graded clean sands. Some steps in their original procedure were either removed or completely modified. Several additional steps were incorporated in the procedure described here to minimize preparation time and increase fines content accuracy. The method, which was used to prepare triaxial specimens of sands containing fines (Carraro 2004), consists of the following steps:

(1) A latex membrane (a 0.3-mm-thick membrane was used) is set around the triaxial base platen and fixed by two o-rings. The triaxial split mold is then mounted around the membrane. The top of the membrane is rolled over the upper part of the mold, and vacuum is applied to eliminate the air gap between the mold and the membrane. The mold is checked for vertical misalignments and, if necessary, leveled and centered. All drainage lines in the triaxial cell are flushed with deaired water.

(2) The dry materials needed for a given mixture are calculated and weighed based on the desired final fines content FC of the mixture [Fig. 3(a)]. Figure 4 shows the relationship between the FC used in the mixtures and the actual FC of the specimens (silty and clayey sands) determined at the end of the triaxial tests. Because clay particles stay longer in suspension than silt particles, larger amounts of nonplastic silt must be incorporated during mixing for a given $\mathrm{FC}$ to be obtained. The weighed sand and fines fractions are placed within a closed container [Fig. 3(b)] and mixed vigorously until homogeneity of the dry mixture is observed [Fig. $3(c)]$.

(3) A cylindrical plexiglass tube closed at the bottom with a rubber stopper is filled halfway with deaired water. A funnel is placed on the upper end of the tube. The dry mixture is poured through the funnel and allowed to enter the tube at a very slow rate to minimize entrapment of air bubbles [Fig. 3(d)]. The funnel is removed, the tube is topped up with deaired water, and another rubber stopper, which has a valve attached to its center, is used to seal the upper end of the mixing tube.

(4) The mixing tube is shaken by turning it upside down repeatedly [Fig. 3(e)] and by rotating it around its axis. The mixing tube is then placed back on the preparation countertop, the upper rubber stopper is removed, and the tube is topped up with deaired water. This step can be repeated several times until all visible air bubbles are removed from the sample (two or three times was found to be sufficient, as long as high-quality deaired water is used and attention is paid to minimize entrapment of air bubbles in step 3; note that, if placement/removal of the upper rubber cap is done 
(a)

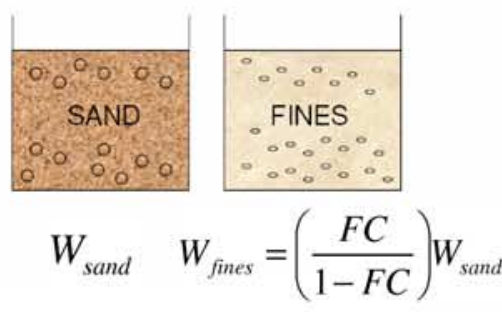

(e)
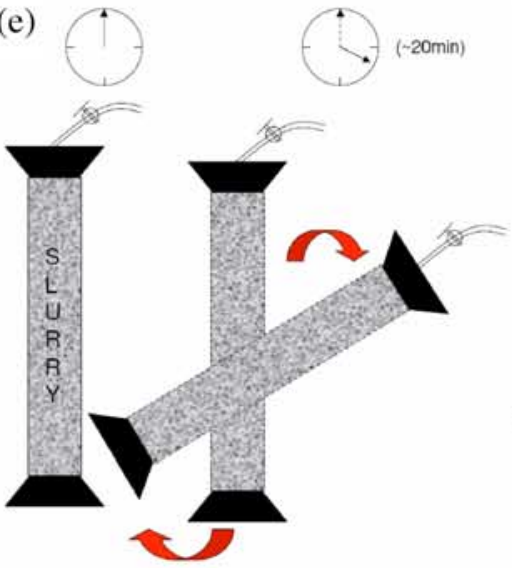

(i)

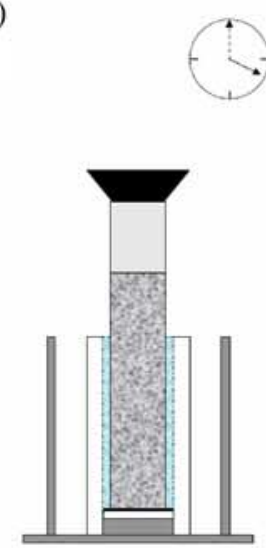

(b)

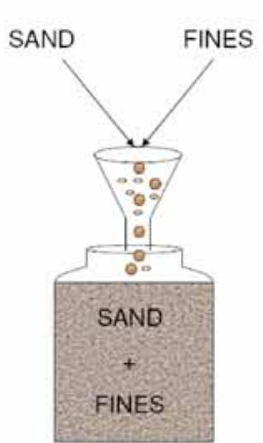

(f)

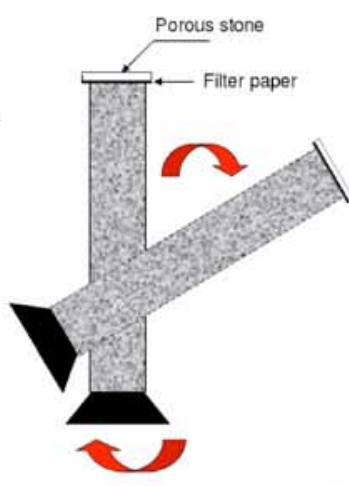

(j) (c)
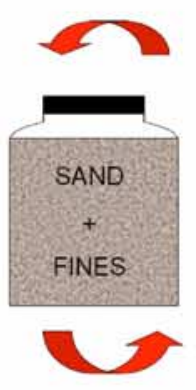

(g)
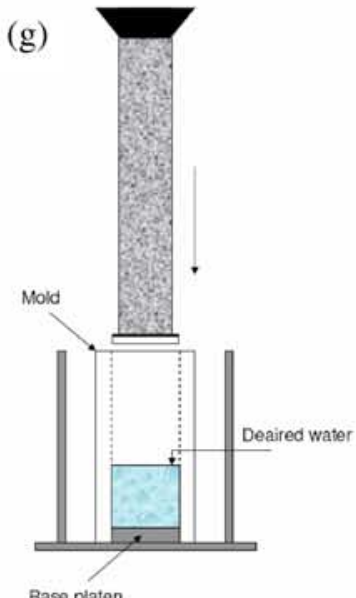

Base platen

(d)

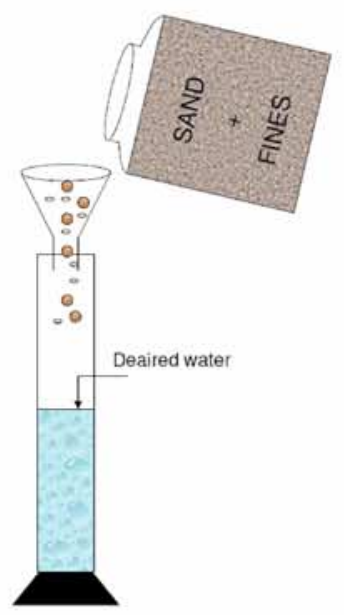

(h)

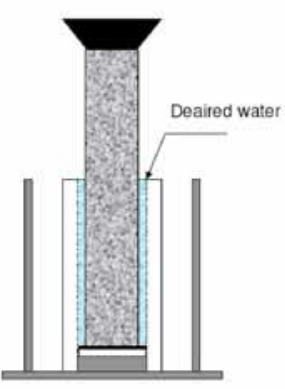

(1)

(k)
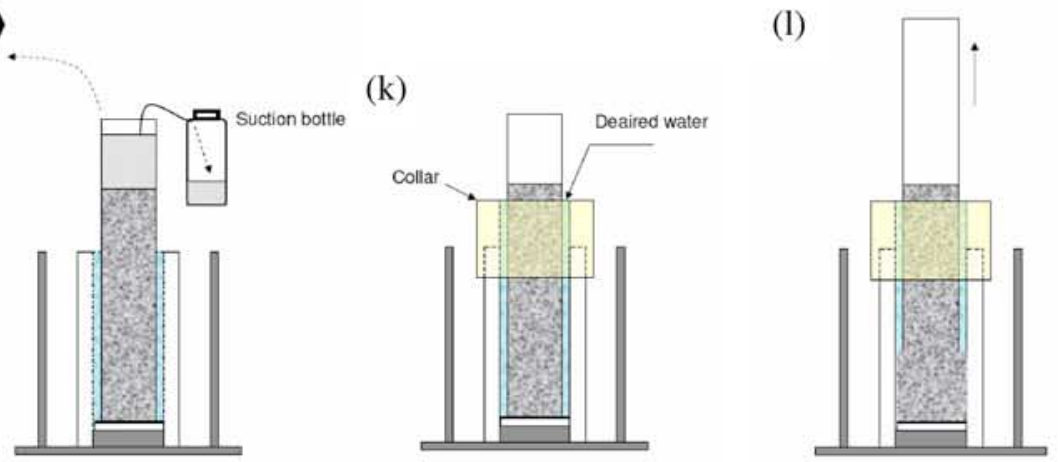

(m)

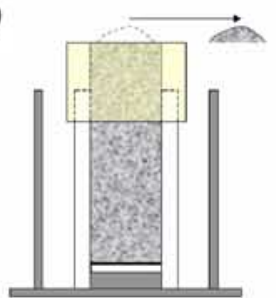

(n)

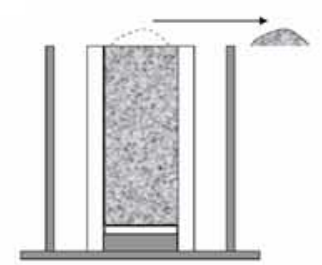

FIG. 3-Schematic representation of the proposed method of reconstitution of specimens of sands containing fines. 


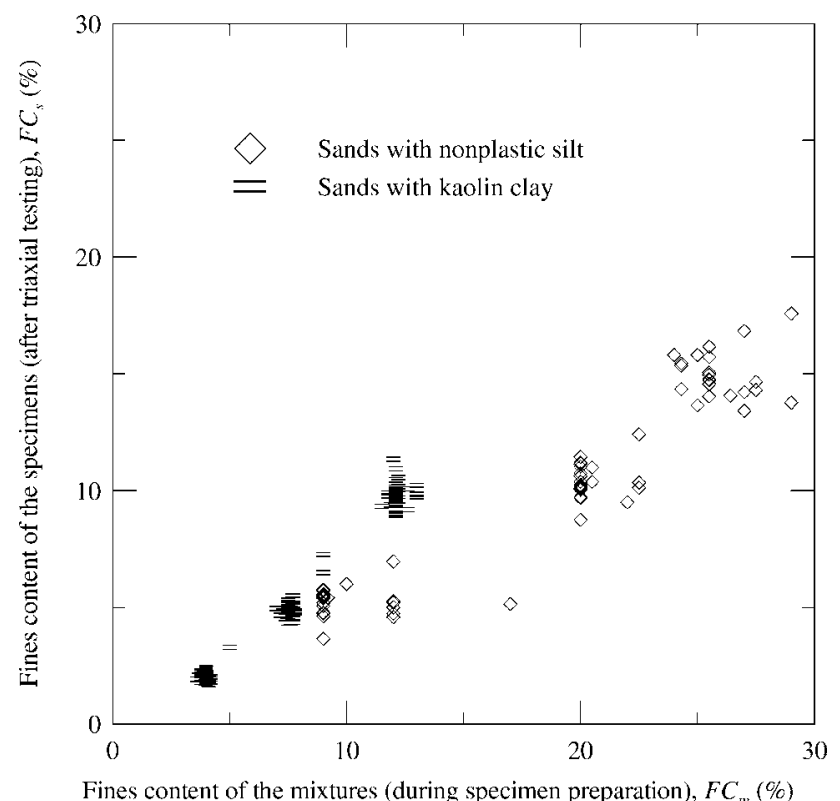

FIG. 4-FC of the mixture of sand and silt or sand and clay versus the actual $F C$ of the specimens determined after triaxial testing.

too many times, excessive loss of fines may occur).

(5) The mixing tube is agitated until mixture homogeneity is achieved - a minimum of twenty-minute-mixing time was found to be adequate [Fig. 3(e)]. The upper rubber stopper is then removed, the tube is topped up with deaired water, and a "sandwich" of Whatman \#1 filter paper and a 3-mmthick porous stone is used to seal the open end of the tube [Fig. 3(f)]. The porous stone diameter is carefully adjusted to be $0.7 \mathrm{~mm}$ smaller than the internal diameter of the mold. This adjustment takes care of the thickness of the membrane and allows the porous stone to fit perfectly inside the mold without damaging the membrane during tube placement. The tube is turned upside down so that the stone-paper sandwich can seal by suction the bottom of the tube [Fig. $3(g)$ ]. The stone-paper sandwich is able to keep the system sealed without any additional support for several seconds. This time is sufficient to allow the tube to be placed within the mold without collapse of the bottom seal. The whole set is then placed vertically inside the mold, the gap between the tube and the membrane is filled with deaired water [Fig. 3(h)], and the mixture is allowed to settle within the mixing tube for about 20 min [Fig. 3(i)]. This rest period is required to allow the mixture to settle down before tube withdrawal. Earlier tube withdrawal may cause loss of the sample, as the unstable slurry may flow out through the small gap between the tube and the membrane.

(6) The top rubber cap is taken out, and the fines slurry remaining at the top of the tube removed [Fig. 3(j)]. A collar is lowered in place, and the gap between the tube and the mold-collar system is filled with deaired water [Fig. 3(k)]. Then, the tube is slowly and steadily withdrawn while the sample is transferred to the saturated mold-collar system [Fig. 3(l)]. The collar is leveled off [Fig. 3( $\mathrm{m})$ ]; the base and side of the mold may be vibrated at this time if dense specimens are to be obtained (Emery et al. 1973; Kuerbis 1989). A small seating load may be used to provide effective con- finement of the top of the specimen during vibration (Vaid and Negussey 1988), while keeping the bottom drainage line open to allow quick dissipation of excess pore pressure.

(7) The collar is removed and the top of the mold is leveled off [Fig. 3(n)] gently to minimize disturbance of the specimen top. The section of the membrane that is rolled over the mold (step 1) is thoroughly cleaned of any soil particles and the top cap is set in place. The membrane is rolled over the sides of the top cap and fixed in place by two o-rings. The top drainage line is connected to the top cap, completely isolating the specimen from the outside.

(8) Vacuum is applied to the specimen slowly and incrementally (up to a maximum of about $20-25 \mathrm{kPa}$ to minimize overconsolidation of the specimen top). After application of the desired vacuum level, the split mold is removed, and any particles that remain attached to the membrane are washed away so that the specimen can be visually inspected for defects.

(9) The specimen height and diameter are measured. Because the vacuum level applied to the specimen at this point is typically equal to the initial confining pressure that will be later on applied by the triaxial system, these measurements can be used to compute the initial volume $V_{i}$ of the specimen. $V_{i}$ values determined in this manner were checked against additional independent measurements based on the gravimetric water content $w$ of the specimens measured at the end of the tests (Sladen and Handford 1987). Appropriate corrections were made for any volume changes taking place during the consolidation and shearing stages. $V_{i}$ values obtained using these two techniques were virtually identical. Thus, the $V_{i}$ values determined in the beginning of the tests can be used to calculate the initial density of the specimens. The typical height and diameter of the specimens were equal to about $160 \mathrm{~mm}$ and $70 \mathrm{~mm}$, respectively.

(10) The triaxial cell is assembled under the loading frame and filled with deaired water. The vacuum level is lowered to about $10 \mathrm{kPa}$ to avoid subsequent overconsolidation of the specimen once the initial cell pressure is applied by the system. From this point on, all subsequent steps can be carried out according to conventional triaxial testing protocol.

Table 1 shows the average and the coefficients of variation (COV) of the fines content and the pore-pressure coefficient $B$ (Skempton 1954) before and after back-pressure saturation of the specimens tested. No particle segregation was observed at any stage of the testing. Note that the $B$ values before back-pressure saturation are higher than the typical initial $B$ values obtained with AP and MT specimen reconstitution techniques. As a result, the proposed method (i) reduces significantly the level of backpressure required to completely saturate the specimens and (ii) eliminates the need for more complex saturation procedures (percolation of $\mathrm{CO}_{2}$ and deaired water through the specimen) that are likely to disturb the delicate soil structure of the specimens and/or affect the accurate determination of their initial soil state parameters (initial void ratio or relative density). These additional saturation procedures are typically required in AP and MT specimen reconstitution techniques, as the initial $B$ values obtained with those methods are extremely low. 
TABLE 1—Statistics of triaxial specimens.

\begin{tabular}{|c|c|c|c|c|c|c|}
\hline & \multicolumn{3}{|c|}{ Clayey sands } & \multicolumn{3}{|c|}{ Silty sands } \\
\hline \multicolumn{7}{|c|}{ Fines content, FC, \% } \\
\hline Theoretical & 2.0 & 5.0 & 10.0 & 5.0 & 10.0 & 15.0 \\
\hline Average & 2.1 & 4.9 & 9.9 & 5.2 & 10.3 & 14.8 \\
\hline $\mathrm{COV}$ & 0.14 & 0.06 & 0.05 & 0.08 & 0.06 & 0.05 \\
\hline \multicolumn{7}{|c|}{ Initial $B$ value (before back-pressure saturation) } \\
\hline Average & 0.69 & 0.67 & 0.65 & 0.61 & 0.57 & 0.73 \\
\hline $\mathrm{COV}$ & 0.28 & 0.28 & 0.26 & 0.30 & 0.37 & 0.25 \\
\hline \multicolumn{7}{|c|}{$B$ value before consolidation (after back-pressure saturation) } \\
\hline Average & 0.99 & 0.99 & 0.99 & 0.99 & 0.99 & 0.99 \\
\hline $\mathrm{COV}$ & 0.00 & 0.01 & 0.01 & 0.01 & 0.02 & 0.01 \\
\hline No. of samples & 30 & 31 & 33 & 22 & 21 & 19 \\
\hline
\end{tabular}

Specimen Homogeneity - One of the main advantages of the SD methods of specimen preparation is that homogeneous specimens of sands containing fines can be reconstituted in the laboratory. Kuerbis and Vaid (1988) replaced the specimen pore water by a low-viscosity gelatin solution using the procedure proposed by Emery et al. (1973) to show that their SD method of specimen preparation produced homogeneous specimens of silty and well-graded clean sands. This procedure allows specimens of sandy soils to be handled without application of vacuum or any other type of external confinement.

The procedure proposed by Emery et al. (1973) was also used to assess the homogeneity of reconstituted clayey sand specimens prepared using the method proposed in this paper. Two procedures are typically used to replace the pore water by a solidifying fluid: the displacement method and the pore fluid method. In the displacement method, time is allowed for the specimen to solidify after pore water is displaced by a solidifying fluid (typically gelatin or epoxy resin). In the pore fluid method, a solidifying fluid is used instead of water throughout the process of specimen preparation. The pore fluid method was selected because displacement techniques may disturb the inherently delicate clayey sand structure.

Regular, unflavored gelatin was used at a low concentration ( $3 \%$ by weight). Viscosity effects were negligible since the specimens were completely prepared within 20 min (Emery et al. 1973). Following preparation, the specimens were left overnight in a water bath at room temperature and then placed in a temperaturecontrolled room at $4{ }^{\circ} \mathrm{C}$ for $5 \mathrm{~h}$. Specimens were then cut into four layers, and the void ratio and fines contents of each layer determined (Emery et al. 1973).

\section{Results}

\section{Limiting Void Ratios}

Despite some criticism, the concept of relative density has been used by several investigators as it allows the description of the density or degree of compaction of sandy soils with respect to the densest and loosest possible states for these soils. The criticism has focused on difficulties in obtaining the limiting void ratios, $e_{\min }$ and $e_{\max }$, particularly for sands with more than $15 \%$ fines content (Burmister 1948; Selig and Ladd 1973; Tavenas and
La Rochelle 1972). However, careful execution of a specific procedure to determine $e_{\min }$ and $e_{\max }$ does lead to values of relative density that are reproducible within $\pm 5 \%$ (Bolton 1986; Salgado et al. 2000). Analyzing data of over 300 natural sandy soils, including clean sands, sands with fines and sands containing small amounts of clay-sized particles, Cubrinovski and Ishihara (2002) showed that the Japanese standard procedures for minimum and maximum densities of sands can be used to obtain reasonably consistent $e_{\min }$ and $e_{\max }$ values for sands with fines content of up to $30 \%$.

The limiting void ratios of the mixtures investigated in this study were determined according to ASTM D 4253 and ASTM D 4254. Table 2 shows the ASTM $e_{\min }$ and $e_{\max }$ obtained for clean, silty, and clayey Ottawa sands. Figure 5 shows a plot of the limiting void ratios versus fines content for these soils.

The ASTM $e_{\min }$ values of silty and clayey Ottawa sands decrease as the fines content increases within the range studied ( $\mathrm{FC} \leq 15 \%)$. This behavior is typical of sands containing less than around $30 \%$ fines and is characteristic of gap-graded mixtures and mixtures whose finer fraction is significantly smaller than the coarser fraction. Similar behavior has been observed in other studies published in the literature (Cubrinovski and Ishihara 2002; Lade et al. 1998; Salgado et al. 2000; Thevanayagam et al. 2002) and is due to the fact that the finer particles occupy the void space between sand particles, reducing the global void ratio of the mixture. Any fine particles originally located between the surface of adjacent sand grains are later displaced into the voids between the sand particles during densification, as $e_{\min }$ techniques require a significant amount of energy (vibration or tapping) to densify the samples.

The ASTM $e_{\max }$ values of the mixtures show two distinct patterns depending on the nature of the fines present in the mixtures. If

TABLE 2-ASTM minimum and maximum void ratios of the sands tested.

\begin{tabular}{lcrrc}
\hline Fines content, FC $(\%)$ & Fines Type & $e_{\max }$ & $e_{\min }$ & $D_{\mathrm{R}, \mathrm{lim}}, \%$ \\
\hline 0 & $\ldots$ & 0.767 & 0.495 & $\cdots$ \\
2 & Kaolin clay & 0.795 & 0.446 & 18 \\
5 & Kaolin clay & 0.810 & 0.432 & 35 \\
10 & Kaolin clay & 0.836 & 0.411 & 58 \\
2 & Nonplastic silt & 0.710 & 0.450 & $\ldots$ \\
5 & Nonplastic silt & $0.700^{\mathrm{a}}$ & $0.420^{\mathrm{a}}$ & $3^{\mathrm{a}}$ \\
10 & Nonplastic silt & $0.650^{\mathrm{a}}$ & $0.360^{\mathrm{a}}$ & $17^{\mathrm{a}}$ \\
15 & Non plastic silt & $0.630^{\mathrm{a}}$ & $0.320^{\mathrm{a}}$ & $38^{\mathrm{a}}$ \\
\hline
\end{tabular}

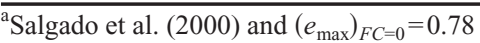




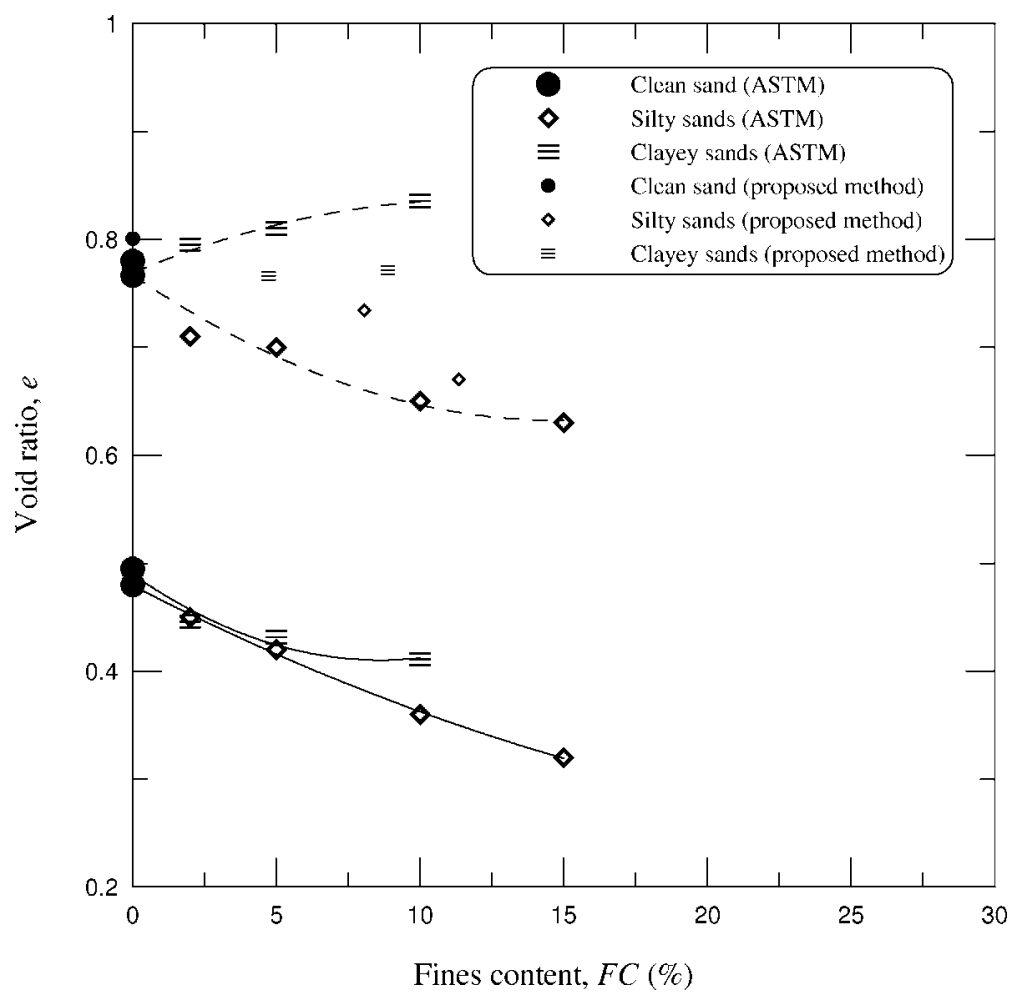

FIG. 5-Minimum and maximum void ratios versus FC of the soils tested.

nonplastic silt is added to the host sand, then ASTM $e_{\max }$ decreases with increasing FC. Conversely, $\mathrm{ASTM} e_{\max }$ increases with increasing FC for sands containing kaolin clay. Since the same technique (ASTM D 4254-Method B) was used for both silty and clayey sand mixtures, it is clear that the nature of the fines present in the mixtures has a major effect on ASTM $e_{\max }$. There are two reasons that this is so. The first is the micro-structural characteristics of the fines. The second is related to the particular details of the procedures used for $e_{\max }$ determination. ASTM standards require use of oven-dried samples, and the drying affects nonplastic and plastic fines differently. The nonplastic fines, which consist of solid quartz fragments, have, in their oven-dried states, a more efficient and compact unit arrangement than the flocculated, clustered structures of kaolin clay. Unlike the $e_{\min }$ techniques, the $e_{\max }$ techniques do not subject the soil structure to enough energy to break or pulverize the clusters or peds of kaolin clay, which are therefore kept relatively intact during $e_{\max }$ procedures, whereas they are pulverized during $e_{\min }$ procedures.

Average $e_{\max }$ values obtained by the new method proposed in this paper are also shown in Fig. 5. Despite the limited amount of experimental data available, these results suggest that, in the presence of water, the clay aggregates (or clusters) existing in the ovendried specimens are reduced in size or eliminated. This reduces the $e_{\max }$ values of the clayey sands with respect to the ASTM values. On the other hand, the $e_{\max }$ of the silty sands are slightly higher than those obtained by the ASTM standard since deposition of sand particles through the silt slurry takes place at constant velocity and under minimum energy. This is because the amount of energy used in the proposed method (pluviation through a silt slurry) imparts less disturbance to the sample than the ASTM D 4254-Method B (quick, vertical tube withdrawal). In addition, the results indicate that pluviation of sand through a clay slurry is similar to pluviation through clean water regardless of clay content in the slurry (Kol- buszewski 1948). Since the sedimentation velocity of the sand is closer to the velocity of the silt material than of the clay, the $e_{\max }$ of the silty sands decreases with increasing FC (Kuerbis et al. 1988), whereas it is relatively constant for clayey sands. Further research is needed to obtain a larger database for different types of sands containing fines.

For a given global void ratio $e$, there is a fines content $\mathrm{FC}$ for which the fines completely (or almost completely) separate adjacent sand particles (Salgado et al. 2000). A practical way to determine the fines content for which this happens is based on the concepts of intergranular void ratio $e_{G}$ (Mitchell 1976) and skeleton void ratio $e_{\text {sk }}$ (Shen et al. 1977). When the coarser and finer fractions of the soil have identical specific gravities (as in the case of the materials considered in this study), the $e_{\mathrm{sk}}$ becomes a particular case of the $e_{G}$ and is calculated as if the fines were voids according to

$$
e_{\mathrm{sk}}=\frac{V_{V}+V_{F}}{V_{S}}=\frac{e+\mathrm{FC}}{1-\mathrm{FC}}
$$

where $V_{V}=$ volume of voids, $V_{F}=$ volume occupied by the fines (particles smaller than $0.075 \mathrm{~mm}$ ), and $V_{S}=$ volume occupied by the coarser fraction of the soil. Whenever $e_{\mathrm{sk}}$ is greater than the $e_{\max }$ of the clean sand, the sand matrix exists with a void ratio higher than it could achieve in the absence of fines, which means that the sand particles are, on average, not in contact; therefore, the mechanical behavior is no longer controlled by the sand matrix (Salgado et al. 2000). For each gradation, a limit void ratio (and a corresponding limit relative density $D_{R, \lim }$ ) can be defined above which a floating fabric exists. The $D_{R, \lim }$ values for the soils tested in this study are presented in Table 2 . 


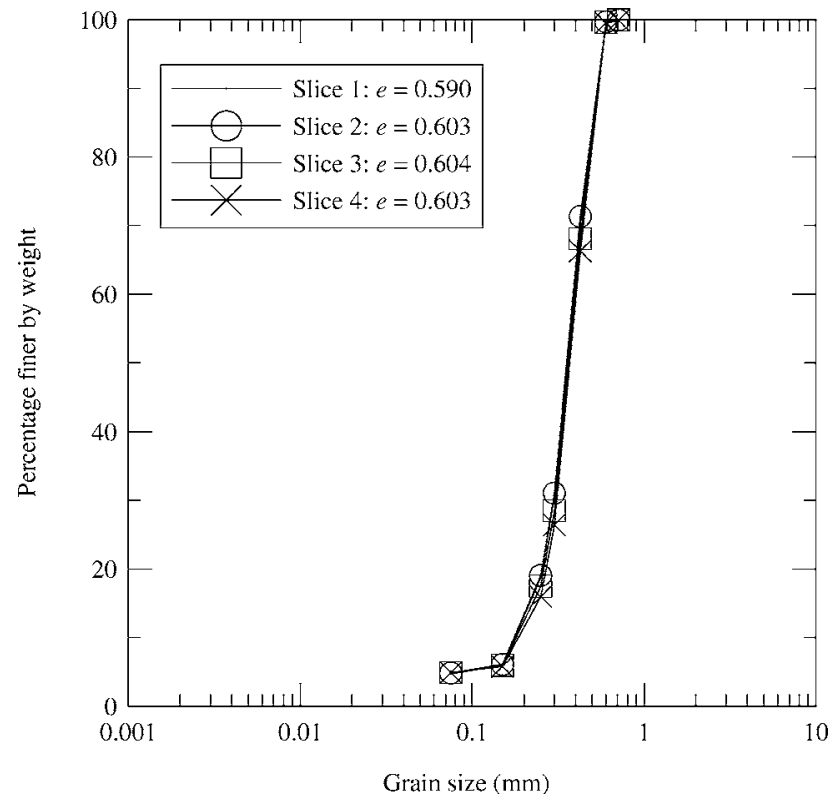

FIG. 6-Grain size distribution curves for the four slices of a clayey sand specimen.

\section{Specimen Homogeneity}

One of the main advantages of the SD methods of specimen preparation is that homogeneous specimens of sands containing fines can be reconstituted in the laboratory (Georgiannou et al. 1990; Kuerbis and Vaid 1988). The gelatin technique (Emery et al. 1973; Kuerbis and Vaid 1988) was used to assess the homogeneity of the reconstituted clayey sand specimens prepared using the specimen preparation method proposed.

The uniformity typically observed for the clayey sand specimens prepared with the proposed method is illustrated in Fig. 6. In this figure, it can be seen that the specimens are extremely homogeneous with respect to their grain size distribution as the gradation curves for the four slices considered are virtually identical. The clay content and void ratio of each slice are shown in Fig. 7. Homo-

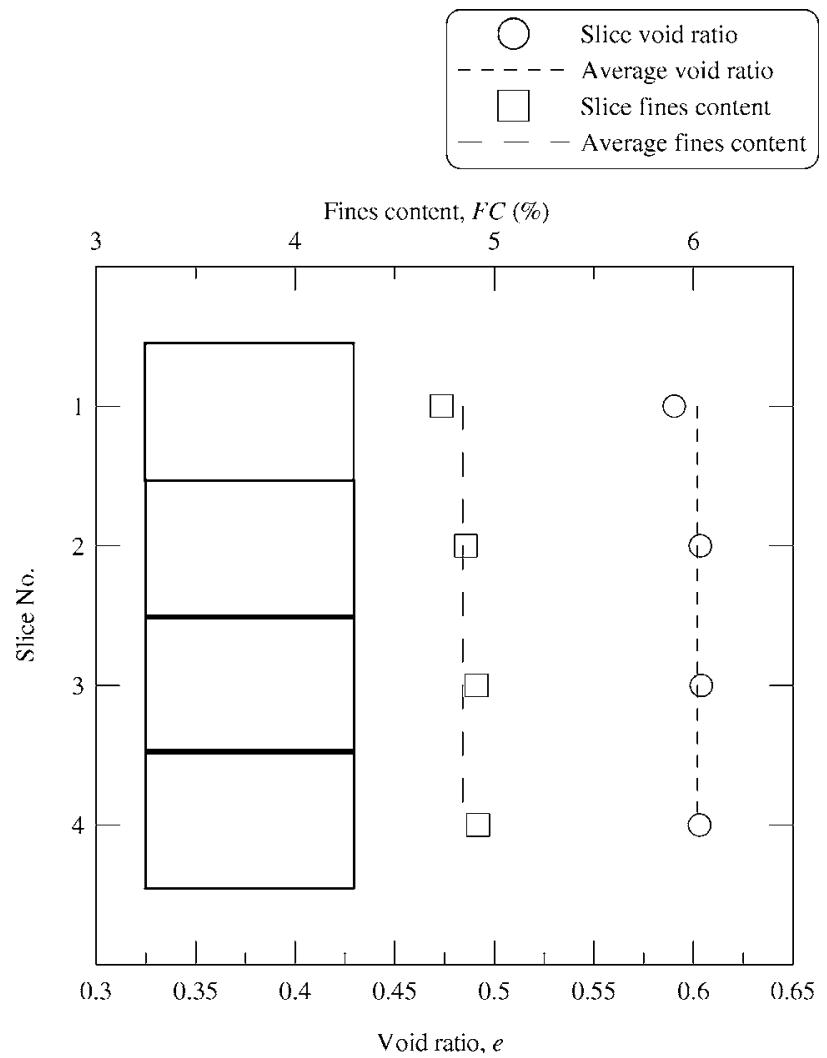

FIG. 7-Void ratio and fines content for the four slices of a clayey sand specimen.

geneity results indicate that the method proposed in this paper can be used successfully to reconstitute specimens of clean, silty, and clayey sands and is appropriate for element testing and studies of the mechanical behavior of these materials. Figure 8 shows typical triaxial compression response, under both drained and undrained loading conditions, for a clayey sand specimen prepared using the proposed method. While soil response depends on soil state, the specimen undergoing undrained loading shows a distinctive stable

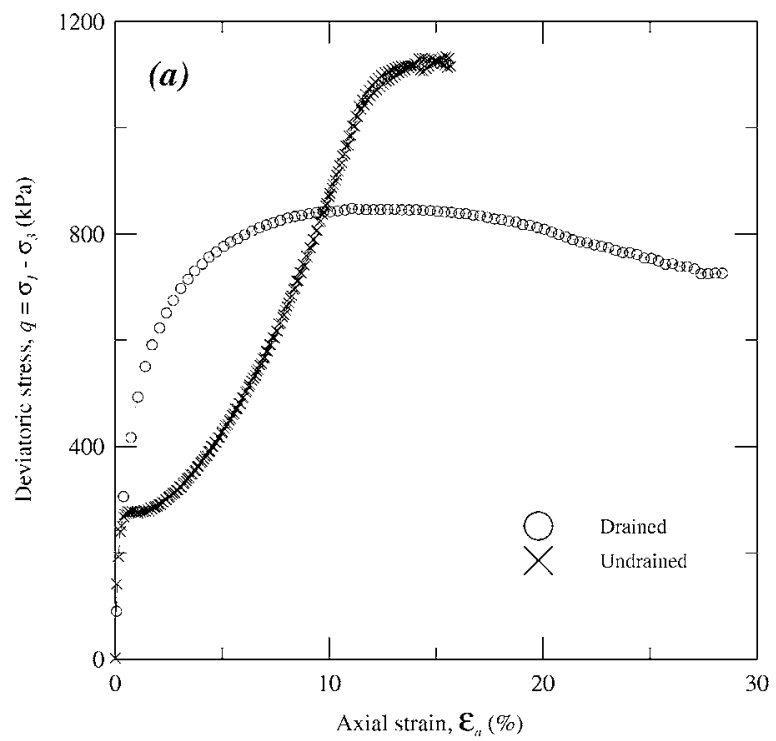

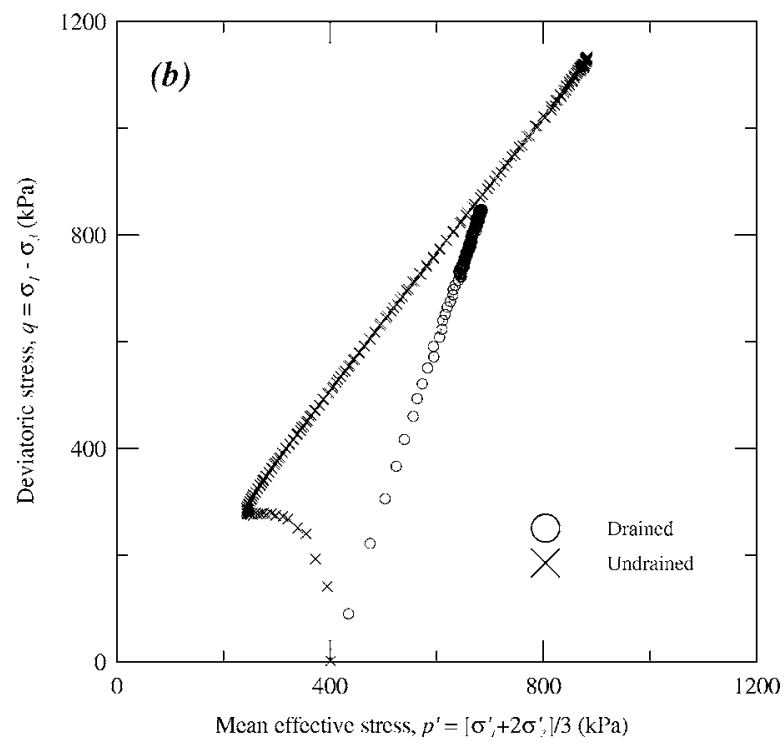

FIG. 8-Typical drained and undrained (a) stres-strain response and (b) stress paths for triaxial compression loading on $5 \%$ clayey sand specimens $\left(D_{R} \approx 64 \%\right)$. 
response over the range of axial strains covered in the test. The characteristic strain-softening response associated with the usually collapsible fabric obtained by AP and MT techniques was not observed for the specimens prepared with the proposed method. As pointed out by several recent studies (Ghionna and Porcino 2006; Hoeg et al. 2000; Vaid et al. 1999), this more stable behavior is characteristic of water and slurry pluviated specimens and natural soil deposits formed under water.

A method of reconstitution of specimens of sands containing either plastic or nonplastic fines was presented. The major advantages of this method are the following: (i) the method allows reconstitution of homogeneous specimens of sands containing fines; (ii) the method produces specimens with a high initial degree of saturation, facilitating subsequent saturation under back-pressure; (iii) specimen preparation can be carried out within 2 to $4 \mathrm{~h}$; (iv) the typical stress-strain response of the specimens resembles the stressstrain response of natural soil deposits formed underwater (Ghionna and Porcino 2006; Hoeg et al. 2000; Vaid et al. 1999).

The limiting void ratios of specimens of sands containing fines vary with the amount and plasticity of the fines added to the host sand. For a given fines content, the maximum void ratio determined according to ASTM D 4254 is higher for sands containing plastic fines (kaolin clay) than for sands containing nonplastic silt. This may be due to the micro-structural characteristics of the fines present in the soil. ASTM D 4254 prescribes the use of dry soil samples, which produces artificially high maximum void ratio for clayey sands. The method proposed in this paper to evaluate the maximum void ratio is applicable to conditions that represent more appropriately soil deposition underwater. Preliminary data obtained with the new technique indicates that, for the soils deposited underwater tested in the present study, ASTM D 4254 overestimates the $e_{\max }$ of sands containing plastic fines, whereas the $e_{\max }$ of sands containing nonplastic fines appears to be underestimated by the current ASTM standard techniques. Additional $e_{\max }$ determinations with the new method proposed in this paper are required for other types of sands containing fines.

\section{References}

Bandini, P., 2000, "Maximum Void Ratios of Silty Sands Determined by Methods A, B, and C (ASTM 4254-96)," Personal communication, West Lafayette, IN.

Bolton, M. D., 1986, "The Strength and Dilatancy of Sands," Geotechnique, Vol. 36, No. (1), pp. 65-78.

Burmister, D., 1948, The Importance and Practical Use of Relative Density in Soil Mechanics, ASTM, West Conshohocken, PA, pp. 1-20.

Carraro, J. A. H., 2004, "Mechanical Behavior of Silty and Clayey Sands," Ph.D. Thesis, Purdue University, West Lafayette.

Carraro, J. A. H., Bandini, P., and Salgado, R., 2003, "Liquefaction Resistance of Clean and Nonplastic Silty Sands Based on Cone Penetration Resistance," J. Geotech. Geoenviron. Eng., Vol. 129, No. (11), pp. 965-976.

Carraro, J. A. H., Bandini, P., and Salgado, R., 2005, "Liquefaction Resistance of Clean and Silty Sands from Cone Penetration," Geo-Frontiers 2005, Austin.

Castro, G., 1969, “Liquefaction of Sands,” Ph.D. Thesis, Harvard University, Cambridge, MA.

Cubrinovski, M. and Ishihara, K., 2002, "Maximum and Minimum Void Ratio Characteristics of Sands," Soils Found., Vol. 42,
No. 6, pp. 65-78.

Emery, J. J., Liam Finn, W. D., and Lee, K. W., 1973, “Uniformity of Saturated Sand Specimens," Evaluation of Relative Density and Its Role in Geotechnical Projects Involving Cohesionless Soils, ASTM, West Conshohocken, PA, pp. 182-194.

Farouki, O. T. and Winterkorn, H. F., 1965, "Mechanical Properties of Granular Systems," Highw. Res. Rec., Vol. 52, pp. 10-58.

Frost, J. D. and Park, J. Y., 2003, “A Critical Assessment of the Moist Tamping Technique,” Geotech. Test. J., Vol. 26, No (1), pp. 57-70.

Georgiannou, V. N., Burland, J. B., and Hight, D. W., 1990, "The Undrained Behaviour of Clayey Sands in Triaxial Compression and Extension," Geotechnique, Vol. 40, No. (3), pp. 431-449.

Ghionna, V. N. and Porcino, D., 2006, "Liquefaction Resistance of Undisturbed and Reconstituted Samples of a Natural Coarse Sand from Undrained Cyclic Triaxial Tests," J. Geotech. Geoenviron. Eng., Vol. 132, No. 2, pp. 194-202.

Hoeg, K., Dyvik, R., and Sandbaekken, G., 2000, "Strength of undisturbed Versus Reconstituted Silt and Silty Sand Specimens," J. Geotech. Geoenviron. Eng., Vol. 126, No. 7, pp. 606-617.

Ishihara, K., Sodekawa, M., and Tanaka, Y., 1978, "Effects of Overconsolidation on Liquefaction Characteristics of Sands Containing Fines," Dynamic Geotechnical Testing, ASTM, West Conshohocken, PA, 246-264.

Kaufman, L. P., Strickland, E. A., and Benavidez, A. A., 1979, "Suggested Method for the Calibration of Vibrating Tables for Maximum Index Density Testing," Geotech. Test. J., Vol. 2, No. 3, pp. 152-157.

Kolbuszewski, J. J., 1948, “An Experimental Study of the Maximum and Minimum Porosities of Sands," Proc., 2nd Int. Conf. Soil Mechanics and Foundation Engineering, Rotterdam, Vol. 1, pp. $158-165$.

Kuerbis, R., 1989, “The Effect of Gradation and Fines Content on the Undrained Loading Response of Sand," Master of Applied Science, University of British Columbia, Vancouver, Canada.

Kuerbis, R., Negussey, D., and Vaid, Y. P., 1988, "Effect of Gradation and Fines Content on the Undrained Response of sand," $\mathrm{Hy}$ draulic Fill Structures, Fort Collins, CO, ASCE, New York, pp. 330-345.

Kuerbis, R. and Vaid, Y. P., 1988, "Sand Sample preparation-The Slurry Deposition Method," Soils Found., Vol. 28, No. (4), pp. 107-118.

Lade, P. V., Liggio, C. D., and Yamamuro, J. A., 1998, "Effects of Non-plastic Fines on Minimum and Maximum Void Ratios of Sand," Geotech. Test. J., Vol. 21, No. 4, pp. 336-347.

Lade, P. V. and Yamamuro, J. A., 1997, "Effects of Nonplastic Fines on Static Liquefaction of Sands," Can. Geotech. J., Vol. 34, No. 6, pp. 918-928.

Leroueil, S. and Vaughan, P. R., 1990, "The General and Congruent Effects of Structure in Natural Soils and Weak Rocks," Geotechnique, Vol. 40, No. (3), pp. 467-488.

McGeary, R. K., 1961, "Mechanical Packing of Spherical Particles," J. Am. Ceram. Soc., Vol. 44, No. 10, pp. 513-522.

Mitchell, J. K., 1976, Fundamentals of Soil Behavior, John Wiley \& Sons, Inc., New York.

Mitchell, J. K. and Soga, K., 2005, Fundamentals of Soil Behavior, John Wiley \& Sons, Inc., New York.

Mulilis, J. P., Arulanandan, K., Mitchell, J. K., Chan, C. K., and Seed, H. B., 1977, "Effects of Sample Preparation on Sand Liquefaction," J. Geotech. Engrg. Div., Vol. 103, No. 2, pp. 91-108.

Murthy, T. G., Loukidis, D., Carraro, J. A. H., Prezzi, M., and Salgado, R., 2007, "Undrained Monotonic Response of Clean and 
Silty Sands-Non-Linear Soil Stiffness in Routine Design," Geotechnique, Vol. 57, No. 3, pp. 273-288.

Oda, M., Koishikawa, I., and Higuchi, T., 1978, "Experimental Study of Anisotropic Shear Strength of Sand by Plane Strain Test," Soils Found., Vol. 18, No. 1, pp. 25-38.

Ovando-Shelley, E. and Perez, B. E., 1997, "Undrained Behaviour of Clayey Sands in Load Controlled Triaxial Tests," Geotechnique, Vol. 47, No. 1, pp. 97-111.

Pitman, T. D., Robertson, P. K., and Sego, D. C., 1994, "Influence of Fines on the Collapse of Loose Sands," Can. Geotech. J., Vol. 31, No. 5, pp. 728-739.

Salgado, R., Bandini, P., and Karim, A., 2000, "Shear Strength and Stiffness of Silty Sand,' J. Geotech. Geoenviron. Eng., Vol. 126, No. 5, pp. 451-462.

Selig, E. T. and Ladd, R. S., 1973, "Evaluation of Relative Density Measurement and Applications." Evaluation of relative density and its role in Geotechnical projects involving cohesionless soils, ASTM, West Conshohocken, PA, pp. 487-504.

Shen, C. K., Vrymoed, J. L., and Uyeno, C. K., 1977, “The Effect of Fines on Liquefaction of Sands," 9th International Conference on Soil Mechanics and Foundation Engineering, Vol. 2, pp. 381-385.

Skempton, A. W., 1954, "The Pore-Pressure Coefficients A and B," Geotechnique, Vol. 4, No. 4, pp. 143-147.

Sladen, J. A. and Handford, G., 1987, “A Potential Systematic Error in Laboratory Testing of Very Loose Sands," Can. Geotech. J., Vol. 24, No. 3, pp. 462-466.

Tavenas, F. and La Rochelle, P., 1972, “Accuracy of Relative Density Measurements," Geotechnique, Vol. 22, No. (4), pp. 549562.

Thevanayagam, S., Shenthan, T., Mohan, S., and Liang, J., 2002, "Undrained Fragility of Clean Sands, Silty Sands, and Sandy
Silts," J. Geotech. Geoenviron. Eng., Vol. 128, No. 10, pp. 849859.

Townsend, F. C., 1973, "Comparisons of Vibrated Density and Standard Compaction Tests on Sands With Varying Amounts of Fines," Evaluation of Relative Density and its Role in Geotechnical Projects Involving Cohesionless Soils, ASTM, West Conshohocken, PA, pp. 348-363.

Vaid, Y. P., 1994, "Liquefaction of Silty Soils," Ground Failures Under Seismic Conditions, Atlanta, GA, ASCE, New York, pp. 1-16.

Vaid, Y. P. and Negussey, D., 1984, "Relative Density of Pluviated Sand Samples," Soils Found., Vol. 24, No. 2, pp. 101-105.

Vaid, Y. P. and Negussey, D., 1988, "Preparation of Reconstituted Sand Specimens," Advanced Triaxial Testing of Soil and Rock, ASTM International, West Conshohocken, PA, pp. 405-417.

Vaid, Y. P., Sivathayalan, S., and Stedman, D., 1999, "Influence of Specimen-Reconstituting Method on the Undrained Response of Sand," Geotech. Test. J., Vol. 22, No. 3, pp. 187-196.

Yamamuro, J. A. and Covert, K. M., 2001, "Monotonic and Cyclic Liquefaction of Very Loose Sands with High Silt Content," J. Geotech. Geoenviron. Eng., Vol. 127, No. 4, pp. 314-324.

Yamamuro, J. A. and Wood, F. M., 2004, "Effect of Depositional Method on the Undrained Behavior and Microstructure of Sand With Silt," Soil Dyn. Earthquake Eng., Vol. 24, No. 9-10, pp. 751-760.

Youd, T. L., 1973, "Factors Controlling Maximum and Minimum Densities of Sands," Evaluation of Relative Density and its Role in Geotechnical Projects Involving Cohesionless Soils, ASTM, West Conshohocken, PA, pp. 98-112.

Zlatovic, S. and Ishihara, K., 1997, "Normalized Behavior of Very Loose Non-Plastic Soils: Effects of Fabric," Soils Found., Vol. 37, No. 4, pp. 47-56. 